DOI: $10.22616 /$ REEP.2020.044

\title{
Craft Entrepreneurship and Created Value
}

\author{
Anzelika Smagina ${ }^{1}$ Mg.oec.; Iveta Ludviga ${ }^{2}$ Dr.sc.admin. \\ Transport and Telecommunication Institute ${ }^{1}$; RISEBA University of Applied Sciences ${ }^{2}$, Latvia \\ anzelikasmagina@gmail.com ${ }^{1}$; iveta.ludviga@ riseba.lv²
}

\begin{abstract}
Craft making is growing and regaining its position both: as hobby and business. Craft industry is experiencing a renaissance and there is evidence of the "third wave of crafting", still research on the craft sector is scarce and craft sector entrepreneurs are little understood in terms of their practices and actions resulting in certain type of value. This study aims to provide an overview of multiple types of value created by craft entrepreneurs in the process of their entrepreneurial actions. Research question addressed by this study is the following: what types of value are created by entrepreneurs in the craft sector in Latvia? This study is explorative, of qualitative nature, based on a case study research strategy. It explores 15 cases, representing craft entrepreneurs and their ventures in Latvia. The results of the study show that craft entrepreneurs create different types of value ranging from materialistic to idealistic by nature and from economic to transformational by the impact: economic and regenerative on one end to symbolic and developmental on the other end of the continuum. The findings of this study can serve as a valuable lens through which to improve an overall understanding of the craft entrepreneurship for entrepreneurs, investors, sponsors and governmental bodies in order to facilitate and support the development of entrepreneurship in the sector and to assess the growth and development potential of the emerging craft ventures.
\end{abstract}

Keywords: entrepreneurs, craft entrepreneurship, created value, craft sector.

\section{Introduction}

Today's world is about economic transformation. Many countries are rediscovering the value and dignity of manual labour, and craftsmanship is, therefore "a sector that is truly capable of leading the local economy, "connecting" important development goals to it" (Bettarini, 2014, 9). Global arts and crafts market is expected to reach USD 50.9 BN by 2024 (Value Market Research, 2018). Recognition of the contribution made by the craft sector in developed countries suggests that it produces an immense non-material value important for the country to sustain its creative potential, facilitate national development while preserving national traditions and cultural heritage (Chapain, Comunian, 2010). Besides, within the broader context of support for small and medium-sized companies in the EU, the European Commission has emphasised support for craft makers and micro-companies established in the industry to revitalise the sector (Bettarini, 2014).

Up to date research on the craft sector is scarce and therefore the sector is less visible than other sectors of the economy. In particular, entrepreneurship in the craft sector calls for better exploration as it is distinguished by a different structure, work conditions, legislation and production of goods which are mostly handmade and have significant input of creativity, national traditions and cultural meanings (Kouhia, 2012). As noted by D. Jakob (2013), craft sector entrepreneurs are little understood in terms of their entrepreneurial practices. Craft entrepreneurship as a niche area has not been in focus of entrepreneurial research, moreover, researchers have identified that understanding the value and impact of the craft sector as probably the most important issues facing the field today (Jakob, 2013). Thus, this study seeks to address this research gap by exploring craft entrepreneurship from a value creation perspective.

Entrepreneurship is the process of creating value and most of the studies and policy documents address created value as an economic variable expressed in economic or financial gain (Baumol, 1990; Birch, 1979; Kirzner, 1973; Acs et al., 2009), which determines the importance of the sector and national initiatives towards its development. However, many entrepreneurs, and it is especially noticed in the creative sectors, do not limit themselves only to the financial interests of the company and in many cases strive for a different impact (McWilliams, Siegel, 2001).

In response to the constantly growing demand for products with not only functional characteristics but also aesthetically pleasing and emotionally engaging (Rintamäki, Kuusela, Mitroen, 2007), the necessity for a new type of entrepreneurial ventures satisfying these new demands has emerged. This, in turn, initiated discussions regarding the necessity to differentiate craft businesses from other types of business 
(Culture Label Agency, 2014). Since the craft sector combines both - commercial and artistic characteristics, entrepreneurship in the craft sector is expected to evolve differently.

Moreover, as noted by D. Jakob (2013), the current generation of crafters aims to "change the world" and transform global capitalism, labour, and social conditions. Therefore, taking into consideration that craft is about handmade objects based on the individual talent and skills of the craft maker, its economic value doesn't seem to be the only value produced (Pret, Shaw, Dodd, 2016). Therefore, this research aims at exploring different types of value created by craft entrepreneurs in the sector.

\section{Crafting and Craft Entrepreneurship}

Depending on national legislation, different countries have different specifications of the professional activities in the craft sector. Understanding what craft is has been changing over the years and up until now, there is no common definition agreed by experts in the area (Tregear, 2005; Ratten, Ferreira, 2017; LucieSmith, 1981; Dormer, 1997). Some mention it is about manual work and functionality, although, others argue it is about creativity, innovation, traditional skills and techniques used to produce craft objects (Risatti, 2007).

According to Oxford dictionary craft is "an activity involving skill in making things by hand" or "work or objects made by hand" (LEXICO, 2019). Similarly, the craft is defined by Merriam Webster dictionary as "an occupation or trade requiring manual dexterity or artistic skill" (Merriam-Webster, 2019). Traditional craft is hand-made; however, contemporary crafting includes also machinery (Mečnika et al., 2014). However, researchers stress the use of only hand-controlled machines in the crafting process (Pöllänen, 2009). In crafting the degree of hand-made can vary, but there must be some features made by hand (Zulaikha, Brereton, 2011). Probably the most concise definition is "craft involves the application of human skill and invested time" (Rosner, 2009, 1).

As there is no common definition of crafts, there is no one common definition of craft entrepreneurship, although it is considered to be the driving force of the development of economies. For the purpose of this research, we combine nowadays available broad definitions of entrepreneurship as creation, organisation and managing a business venture (Gartner, 1990) and above-mentioned definitions of crafts and propose the following meaning of craft entrepreneurship - creation, organisation and managing a business venture which involves application of human skills and hand-work and involve the creation of utilitarian products or services with some degree of aesthetic value. Thus, a craft entrepreneur is someone, who earns his/her living by creating something of value partly using hand-work.

\section{Entrepreneurship and Value Creation}

There are many definitions of entrepreneurship arguing if it is about behaviour or outcomes; if it is part of the commercial sector or the not-for-profit one; if it is about small or individual ventures (Gartner, 2001; Hébert, Link, 1982; Kirzner, 1983), however, the very central role in the discussion is given to the importance of opportunity recognition and setting up enterprises. Analysing the nature of entrepreneurship from Kizner's perspective (Kirzner, 1983), entrepreneurship consists of the competitive behaviours that drive the market process and without outcome, there is no entrepreneurship. According to (Gangi, 2015), a reciprocal exchange of value exists between markets and businesses. In this sense, value-creating outcomes are very important. A. Klamer (2011) mentioned that value is a notion, which has not yet been well defined. He explored the cultural-economic perspective of value from a historical perspective and pointed out that in origin, value is coming from the perspective of classical economics and it signifies the "worth of a thing".

As stated by D.G. Sirmon (Sirmon, Hitt, Ireland, 2007), value creation begins by providing some kind of value to customers, however, entrepreneurs may want to create also value that goes beyond economic interest, something that contributes to community and society. Value or outcome of entrepreneurial actions can be viewed in terms of "total wealth" which is a combination of economic and social wealth and includes tangible and intangible outcomes. Tangible could be defined as products or services, and intangible as happiness, motivation, general well-being and other types of value. As mentioned by A. Klamer (2011), there is a need to distinguish other values (for example, social and cultural) from economic values. While the economic perspective can be presented in figures and hard evidence, this perspective is quite limiting and doesn't take into consideration the "soft" nature of the outcomes 
produced. For instance, the value created in arts and culture is defined as intrinsic value - values which make people feel, engage in experiences, establish emotional connections (Mowlah et al., 2014).

As stated by cultural economist D. Throsby (2008), values can be created in different forms and come from different contexts. Because of the elusive nature of the term, it is better to study it in a real-life setting - where it is created and where people perceive it as something valuable. Not all the enterprises in the craft sector are the same and not all create the same value. Understanding the different forms of value created by craft entrepreneurs would contribute to a better understanding of the sector.

Thus, the aim of this study is to identify types of value created by craft entrepreneurs in the process of their entrepreneurial practices and actions.

\section{Methodology}

Following an initial pilot study about entrepreneurship in the craft sector in Latvia, it was identified that value created in the craft sector had not yet been studied in detail and field is in need of development and better understanding. Thus, addressing this gap in the research, the following research question was put forward: "What types of value are created by entrepreneurs in the craft sector in Latvia?".

Thorough literature review on entrepreneurship in the craft sector was carried out to identify the boundaries of the research and to choose appropriate research design and methodology. Thus, exploratory qualitative research methodology with grounded theory approach, which is the most suitable to investigate a field not yet explored in detail, was chosen. Grounded theory approach involves generating research framework, themes, categories (variables) and building a theory from the data obtained directly from the field in the process of conducting research (Corbin, Strauss, 1998). One of the ways to use grounded theory approach is the case study method, which includes multiple techniques of data collection - observation, interviews, analysis of secondary data and others. It allows gathering in-depth information and evidence from real life situations, thereby allowing to conceptualize the findings directly from the field (Yin, 1994).

Cases have been chosen to provide for a diverse view on the practices of Latvian craft entrepreneurs of different professions, ages as well as types of business. The purposeful sampling strategy has been used to identify information-rich cases to provide a full set of details with a limited number of the chosen craft cases (Patton, 2002). In order to ensure validity of data, cases were identified and selected on the basis of the following criteria: founder of the venture or his venture is identified as belonging to the craft sector; core activity of the venture (craft making) involves significant input of manual labour, venture is registered in Latvia (for the purposes of this article). In selecting the cases it was assumed that founders of any type of craft business all have economic (i.e. financial) objectives. Not-for-profit sector (i.e. charities, voluntary and public sector) organisations were not included in the research. To enrich the body of the research and to identify common patterns and characteristics on different levels of analysis, cases of self-employed craft entrepreneurs as well as small and micro enterprises have been explored. New cases had been identified and analysed until theoretical saturation was reached.

Multiple sources of data about the cases were used to come out with the findings; however, primary data about the cases was collected using semi-structured interviews with the craft entrepreneurs - founders of their own craft ventures. Interviews with the elements of a narrative approach were conducted in order to give the interviewees the possibility to provide as many details as they felt comfortable to share. Interviews with the 15 entrepreneurs were carried out in Latvia, in the native language of the interviewees (Latvian or Russian) during the period of 6 months from January to June 2019. Interviews were recorded and transcribed. Taking into consideration the different motivations and actions of craft entrepreneurs, when engaging in entrepreneurial undertakings, the aim of the interviews was to explore diversity of value created in the sector. To better understand craft entrepreneurs and their value-creating actions, during interviews, entrepreneurs were asked a series of structured questions regarding themselves, their business and experience. Further, entrepreneurs were asked to describe the value they create in running their business in the craft sector as well as reason why they do so (sample questions: How would you describe the value created by your craft business and its impact on different levels? Who can benefit from it and how? How is it connected to the "philosophy" of your business and your personal motivation? What is important for you in terms of creating value? and so forth). 
Collected data was processed and analysed by means of NVivo software. It was coded and analysed using iterative process going back-and-forth in between the stages of analysis to identify relevant themes and concepts and conceptualize the findings (types of value), which are presented in the section of findings. Direct quotation technique was used to describe each type of the created value.

\section{Results and discussion}

The focus of this research was to explore and conceptualize the value created by entrepreneurs in the craft sector. Most of the previous studies indicate that value can be placed on a continuum between the two types - economic and social. However, taking into consideration that the craft sector is different in comparison to other sectors, this study explored if craft entrepreneurs create other types of value. The findings suggest that the continuum between economic and social values should be extended adding other types of value created in the craft sector. Further, description of each type of value is presented. It is illustrated by presenting extracts from the interviews with the entrepreneurs.

Economic Value. One of the features of craft good is its financial value, which can be very high not because of their functional characteristics but their uniqueness, aesthetics, name of the creator, trends in society, and others. As one of the interviewees mentioned:

I see a new trend in society - suddenly there is such a high demand for traditional wear and people are ready to pay a very high price to get a tailor-made dress, which would be unique, especially with elements of the national costume. I do not prioritise financial gains over quality and message I like to convey with my products, but I make a good living out of this (Case 7).

Despite the common perception that creative people are poor, craft entrepreneurs who set up their enterprises and are successful, prove that being an entrepreneur in the Craft sector allows for one to successfully combine being creative and earning a living. As confirmed by the interviewee:

I am excited about my "job" and it works well for me, although, I would like that the craft sector in Latvia to develop and craft goods are fairly priced and appreciated. I believe it has a much higher value than what we sell at the moment. Take Scandinavian countries... there, crafts are quite expensive... and one can earn a much better living (Case 13).

Entrepreneurship is about the creation of value and craft entrepreneurship is not different in this sense, as it is about developing a certain opportunity, setting up a business venture while initially pursuing an economic value in order to make it feasible and sustainable. However, we conclude that economic value pursued by craft entrepreneurs is more functional - it serves the purpose of creating a financial pillar and allowing creative entrepreneurs to pursue other values, which, as indicated by the cases, are more important for them than the economic one. The craft sector in Latvia also contributes to national wellbeing, however, not yet to its full potential. Still, the Craft sector's direct impact is reflected in its contributions to the budget, formation of new business ventures and employment.

Regenerative Value. Regeneration benefits accrue craft entrepreneurs take part in national events, markets, workshops, festivals and cultural manifestations organized in different urban and regional locations. Such events draw attention and bring people to these places, thus promoting the location and facilitating its development. Craft markets are a great example of how places become crowded with locals and tourists alike contributing to the development of the area - allowing other businesses there to benefit in terms of increased sales, better visibility (more people see the place and consequently use its services and products - for example, cafes, shops, restaurants, located near the venue).

The presence of craft shops, galleries, workrooms, studios or craft markets improves the image of a city and creates a positive atmosphere so that locals and also tourists perceive it in a better light. It draws the attention of people to arts, crafts, national and cultural traditions, and heritage. It has a positive effect on being a new emerging trend as well as engaging people in the life of their city, making them "connected" to their locale. Thus, having a positive and pleasant experience when being in their area, people become more loyal and supportive of their development. For instance, one of the interviewees mentioned:

Riga used to be crowded with young people having parties and making the city unattractive for other tourists and locals... now it all changed... all the cultural events, festivals, and craft markets brought forward a different image of Riga. We are so proud to contribute to the nomination of Riga as a capital of culture in 2014 (Case 3). 
Environmental Value. The empirical evidence from the cases indicates that most craftsmen use local, environmentally friendly materials. As interviewee from C9 implied:

I am very serious about the quality of my products and therefore the materials I use have to be of appropriate quality. Mostly, I buy from local producers and use raw materials. Sometimes, I can even collect stones and pieces of wood myself. In doing so I feel connected to nature and living in balance with it (Case 9).

Across the cases, it was observed that craftsmen also like to get across that their products are "eco" and environmentally friendly and confirm it by special certificates certifying its quality. They also use it as one of their selling points. For instance, one interviewee positions his product in the following way:

The idea behind my product is to produce high-quality goods with a touch of nature, thus, using environmentally friendly materials and complying to the environmentally cautious ways of production and restoration (Case 4).

Although Latvia has a lot of forests that cover more than $50 \%$ of the land, Latvians are very cautious about it. Wood as a source of natural material is widely in craft practices, although, respondents mentioned it is also important for them to "give it back to nature" (Case 10):

We have a fantastic nature in Latvia and can use local materials. The birch and oak I use for my craft are of great quality and my customers appreciate that.... And in Latvia, we use it a lot, but we also replant new trees and take care of the forests' vitality and health (Case 3).

Thus, as noted by L.E.E. Walley and D.W. Taylor (2002), all green businesses also contribute towards the move to a sustainable society.

Educational Value. The educational value of the Craft sector was highlighted when informants spoke about training and transferring knowledge to their apprentices. Especially in the Craft sector, it is important to teach all the specifics of the process to make sure it is done properly. The crafting process involves a significant manual input (products are hand-made) and it is important to pass on all the knowledge so that important details are not lost over time and apprentices learn many traditional forms of craft. Craftmanship is about mastering traditional skills and techniques and teaching those to younger people to help preserve traditional craftsmanship and assist younger generations to learn from the past:

A lot of traditions have been lost over the years and it is very sad; therefore, in my work, I strive to preserve traditional practices and keep it "old style". I also organize small workshops for children and others interested in my craft so that I can share my knowledge and preserve traditional practices (Case 9).

However, the educational value is not only about teaching and learning, but it also facilitates an interest in craftsmanship and, consequently, people learn more about the cultural heritage of craft. Such learning is the most tangible manifestation of inter-generational skills transfer:

Everything I do in my workshop is observed by my children... sometimes they help me... it is extinctions as they are learning from me meaning they would be able to practice it latter (if they wish so) (Case 5).

Besides, several respondents mentioned that working with apprentices as well as learning and practicing craft helped them become more confident, skilled and eventually more professional.

Innovation/creation Value. Even though the craft is perceived as something traditional, rooted in the past, many craftsmen take advantage of the new advanced materials and technologies to improve their products and services. And these new combinations of traditional and contemporary practices nourish creativity and facilitate innovation in the craft sector. As one of the interviewees indicated:

Latvia is a small country and it needs to encourage the production of goods with high added value based on creativity and innovation (Case 11).

The craft sector can offer goods with high added value. In the process of creation and production innovation and creativity emerge as a spill-over effect into other sectors and industries of the economy. As one interviewee observed:

Value in the craft sector is different - it is a value, which emerges as the result of individual creativity and the unique way of production practiced by craft makers. It is what makes it so 
valuable not only for the craft maker but also for society. Innovative goods and practices emerging in the craft sector can be transferred into other sectors of the economy (Case 14).

Another entrepreneur confirmed in the same way:

Some people think that all my baskets are the same, however, that is wrong. As I do each one by hand and from natural materials, every basket is different. I don't have a fixed plan of how and what to produce...when I have inspiration, I create something new...I might also incorporate different objects, colours, materials in my work... it all depends on how creative Ifeel on a certain day [big smile] (Case 8).

Besides, as was noticed by some respondents, craft makers are like artists - they also look for inspiration and find it in the work of their peers, in attending galleries, markets, cultural events, and festivals. Thus, by appreciating the work of others they capitalize on that creative output to create their own.

Another key contribution was mentioned by the respondent from Case 1:

Being involved in craft making every day helps me to sustain and develop my creative spirit. It is my craft and I am not limited... I can create it as I like and how I feel (Case 1).

Also, another entrepreneur confirmed the same view:

I have chosen to set up my own business because I can create... I don't need to discuss my work with anyone and I am free to let my creativity and talent work for me... if I see I can't sell it, I might think how to change it... but consistent with my way of seeing and creating (Case 8).

Cultural Value. Some interviewees mentioned they would like to contribute to the development of their city by making it attractive for tourists as well as locals as a place where a lot of cultural events happen: I like to be part of that creative atmosphere in the craft markets organized by the City Council around Christmas. It makes me proud of what I do and I feel I can contribute to my city image as a "capital of culture" and help tourists realize we have a very rich cultural heritage (Case 7).

Craft enterprises are creative by nature and all new shops, studios, galleries, and workshops strengthen the cultural image of cities, attracting more creative people to join. As mentioned in several cases, recent years have seen a developing trend whereby people come to Latvia because of the possibilities it offers in terms of culture and arts. They appreciate the exhibitions, concerts, festivals as well as the many shops and craft markets offering hand made products.

Social Value. People are social beings and they tend to associate themselves with a certain group. Even though many craft entrepreneurs establish micro-companies they spend time with other craft makers to practice their art together or attend different workshops and events. As was mentioned:

When I meet with my colleagues from the craft sector, I feel I belong to a group of people I understand, and I am comfortable with it. We appreciate each other's work, support and praise each other - it is very important for our small community (Case 11).

Another entrepreneur acknowledged:

Knowing each other in our field is important... network is everything... thus, our craft brings us together to collaborate and partner in some cases (Case 13).

Craft entrepreneurs described their social value in terms of helping individual craft makers in terms of employment, referrals, and sales of products. Many craft makers are entrepreneurs and they appreciate those who help them find their customers and sell what is created and produced. As stated by the entrepreneur:

In our field referrals are important - we trust our peers and we engage in short term projects if needed. It suits me well - I always get offers and I can decide if I want to take part or not (Case 12).

Engagement of people in cultural events is a great example of how craft entrepreneurs contribute to community development.

However other interviewees mentioned that relations between entrepreneurs and individual craft makers they deal with in business are not easy:

Creative people need a special approach and attitude... they need to be inspired, motivated, supported. Motivation is different for them and I always have to be patient, "nice", encourage them... It helps me develop my social skills a lot [laughing] (Case 8). 
Crafts entrepreneurship helps to sustain the creative community of craftsmen by getting them involved in associations, building connections with other industries thereby creating a sort of cluster for craft makers to practice their craft and prevent social exclusion, isolation or "loneliness" of the creative person.

Aesthetic Value. Respondents mentioned that creating a product, which is beautiful and aesthetically pleasing, is part of their work:

Craft is about art, creativity, and aesthetics. It just has to be beautiful and spark positive emotions (Case 2).

Another respondent added:

I like to change things for the better and in my business, I have the possibility to make unique, tailor-made things so that people appreciate the beauty of how it looks. I like to see this positive change and the emotions expressed in response (Case 6).

Although aesthetic value is not the most important one mentioned by respondents, it is placed very high in their hierarchy of created values. All respondents mentioned that their craftwork is aesthetically pleasing and reflects their identity, which is expressed in its meaning, intentions, and purpose. Besides this external characteristic of the product, the aesthetic aspect conveys the quality of the product in terms of professional production, highquality materials as well as the technical competence of the craft maker. As an interviewee stated:

In my pictures, I try to catch people when they look natural, relaxed and therefore beautiful. Everyone is beautiful but in his/her own way. I try to show it by capturing these moments and show people themselves but from a different angle... and they usually like what they see [big smile] (Case 14).

Heritage Value. Craft entrepreneurs help to preserve cultural heritage, especially in cases of practicing the traditional craft. Such craft objects convey cultural meanings, traditions in its colours, style, functionality, and aesthetics. Also, the way of production is based on ancient, traditional techniques as well as a significant manual contribution. Craft objects reflect the social practices of the country - very popular images used in craft objects are people dancing, singing together, celebrations, Midsummer rituals, and others. They reaffirm the identity of the people of the country and bring them together.

Respondents noticed that they would like to promote the Latvian way of living, our national cuisine, and history and see them reflected in traditional craft objects and in the stories told by craft practitioners. The interviewee exemplified this:

Nowadays people look for inspiration in the old days - they look at what our grandparents did, what they valued and what traditions they had. Now creative entrepreneurs want to bring it all back and pass it on to future generations sharing with peers, children, the younger generation, as well with the international community (Case 12).

Other comments expressed by respondents regarding the value of their products were in relation to its long-term value - value, which won't vanish in a few years. That is why they like to embed culture, traditions and national symbols in their products - to make them sustainable and valuable in the long run. As stated by the entrepreneur:

Latvian craft sells well; it is highly appreciated by people, who value high quality and traditionally designed products (Case 11).

In several cases, respondents confirmed their determination and willingness to promote Latvian traditions, and rituals. Many of the creative entrepreneurs' products include Latvian symbols, reflecting Latvian nature, people, traditions, and others. Most of the craft entrepreneurs mentioned they would like to promote Latvia and products made here. As one of them stated:

It seems that a lot of Latvian heritage has been lost over time - partly because of historical events and partly because of the transition to mass production. We need to restore it and pass it along to the next generations.... It is important for me to contribute to it (Case 5).

Artistic Value. Artistic value as expressed by the respondents is a value, which respondents attributed to their crafts as being a piece of art. In this respect, craft entrepreneurs appear to be like artists who acting increase opportunities to enjoy and appreciate aesthetic beauty (Gangi, 2015). As one of them indicated:

We all have a creative spirit and soul. We are all artists and our craft is an art. It might not sell for millions, but it definitely has all the characteristics of what art is (Case 4). 
As further explained by the interviewees, craft making involves the same processes as art and the only difference is that craft objects are also functional whereas art is not. Artistic value is about the value artists are putting into their works. These properties are unique for each piece of art and even if, in the case of art one piece might be reproduced in some quantity, it still represents a unique product made by the individual craft maker. Artistic value is also about the person who produced the craft object. It reflects their achievements, experience, and reputation. And this individual artistic value might be reflected in different ways. The Case 6 respondent said:

I worked hard to achieve what I have and now I can offer my craft not only as a beautiful piece of art but also as something produced by me... I think people recognize me as a good artist already (Case 6).

In fact, both, arts and crafts are considered to be based on the creative input of the individual, however, the difference is that art is something closely connected to emotions, unstructured and subjective, meanwhile, craft has a sort of tangible and useful output - a piece of craft which has functional value. Another difference mentioned by the respondents is that "art is the creation of the soul and heart while the craft is the creation of mind and skills" (Case 4). Therefore, when these two dimensions meet, they create synergies and consequently creative and innovative products and solutions.

Symbolic Value. The symbolic value embedded in goods is based on the entrepreneurs' intention to convey a certain meaning. Values people assign for certain things depend on their identity and the way they see the world (as indicated by Case 7). In some cases, these meanings are unique to the local context and if placed in a different environment could have another interpretation. The symbolic value is of special importance for the craft sector as it conveys value embedded in culture, traditions, and history. As confirmed by the respondent in Case 14, people assign a certain symbolic value to a product and it serves them as a token or memento of certain events, experiences, people, feelings, and others. In addition, the respondent in Case 9 added:

When I sell my souvenirs, I like to tell stories about the past... it is because I like people to remember it and I like that my souvenir will be associated with my stories and people will remember (Case 9).

However, the symbolic value assigned to their products by the customers might be different - the story attached to the product can be real or imagined, related to place or event or to symbolic item, it can be even transnational or transcendental.

Developmental Value. Personal development and transformation is an important part of any process and all respondents confirmed that they appreciate the possibility of personal development when practicing their craft. It gives them freedom of expression, self-fulfilment and talent development, which is a major motivator for engaging in entrepreneurial practices. Respondents highlighted the value of the lifestyle they have chosen (run their own enterprise) and the value of practicing their craft at their own pace and style. In their handmade craft objects, they have the possibility to express their emotions, feelings, likes, and dislikes as well as the philosophy they wish to convey to the external world. Respondents also referred to self-discovery and a better understanding of others, which comes from making craft objects. As one of the respondents stated:

When I am making my "pieces of art" I feel and understand myself better. The process gives me the possibility to think and create, like and dislike... I think about it... and it also helps me to understand others better... I see what people like and how they perceive my craft. I know we are all connected... the things I create inspire others and I get inspired by what they offer ... it is an ongoing process of creation based on inspiration and the internal drive to create... that helps me sustain my business and develop my talent and skills (Case 2).

Craft entrepreneurs reported the importance of self-fulfilment and self-realization in their professional life. As confirmed by many cases $(3,5,6,8,9,12,13)$ that is what they are able to realize when working in the craft sector. This intangible value expressed in terms of personal satisfaction is why creative entrepreneurs engage in business. As reported by the interviewee in Case 5:

My business brings me happiness and makes me proud of what I am doing. I feel my talent is appreciated and it is what drives me more than making money. It is, probably, one of the most important outcomes of my business for me (Case 5). 


\section{Framework of Values Created in the Craft Sector}

On the basis of interviews, observations and other information available about the cases of this study, framework of different types of value created has been built (Table 1). Although, the interviewed entrepreneurs mentioned multiple types of created value, for the purposes of this study the authors ranked those in terms of significance as perceived by the entrepreneur. Values have been ranked from 1 (the most significant) to 3 (the third significant) in order to provide a comprehensive overview of the types of value and be able to compare the cases and notice certain commonalities. The table also presents the continuum of the values, flowing from tangible or materialistic to intangible or idealistic values. Even though the cultural or artistic value could still be expressed as tangible, subjective value has purely of an intangible, non-materialistic nature (Table 1). Offered framework of values also offers 4 broad categories of values: economic, social, artistic and transformational along the continuum from materialistic to idealistic values.

Table 1

Values Created by Entrepreneurs in the Craft Sector

\begin{tabular}{|c|c|c|c|c|c|c|c|c|c|c|c|c|c|}
\hline \multirow{3}{*}{ 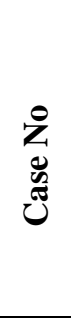 } & \multirow{3}{*}{ Case characteristics } & \multicolumn{9}{|c|}{ Materialistic } & \multicolumn{3}{|c|}{ Idealistic } \\
\hline & & $\begin{array}{l}.0 \\
\tilde{\Xi} \\
0 \\
0 \\
\text { I } \\
\end{array}$ & 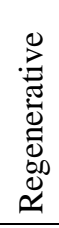 & 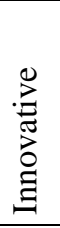 & 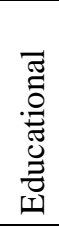 & 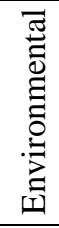 & $\begin{array}{l}\frac{\pi}{0} \\
0 \\
0\end{array}$ & 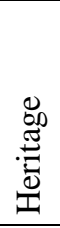 & 吾 & 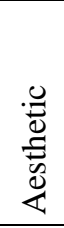 & 总 & $\begin{array}{l}: \frac{0}{0} \\
\text { है } \\
\text { जी }\end{array}$ & 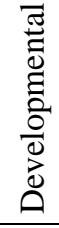 \\
\hline & & \multicolumn{8}{|c|}{ Economic } & \multicolumn{4}{|c|}{ Transformational } \\
\hline $\mathrm{C} 1$ & Jewellery design & 1 & & & & & & & & & 2 & & 3 \\
\hline $\mathrm{C} 2$ & $\begin{array}{l}\text { Floral design, craft clutches, } \\
\text { accessories }\end{array}$ & & & & & & & & & 2 & & 3 & 1 \\
\hline $\mathrm{C} 3$ & Installation, repair, renovation of roofs & & 1 & & & 2 & & & 3 & & & & \\
\hline $\mathrm{C} 4$ & Furniture, interior design, restoration & & & & & 2 & & 3 & & & 1 & & \\
\hline $\mathrm{C} 5$ & Restoration of musical instruments & & & & 3 & & & & 2 & & 1 & & \\
\hline C6 & Face and body art & & & & & 2 & & & & 1 & & 3 & \\
\hline $\mathrm{C} 7$ & Folk wear and accessories & & & & & & & 2 & 1 & & & 3 & \\
\hline $\mathrm{C} 8$ & $\begin{array}{l}\text { Decor set up, design, event } \\
\text { management }\end{array}$ & 1 & 2 & & & & & & & & & 3 & \\
\hline C9 & Pottery, woodfired clay tableware & 3 & & & & & 2 & & & & 1 & & \\
\hline $\mathrm{C} 10$ & Beekeeping, honey bee production & 1 & & & & 2 & & & & & & & 3 \\
\hline C11 & Wool, willow processing and weaving & & & & & & 1 & 2 & & & & & 3 \\
\hline $\mathrm{C} 12$ & Sauna rituals & & & & & & & 1 & & & & 2 & 3 \\
\hline C13 & Boatbuilding and restoration & 1 & & & & & 2 & & & & & & 3 \\
\hline $\mathrm{C} 14$ & Photo frames and postcards & & & & 2 & & 1 & & & & & 3 & \\
\hline $\mathrm{C} 15$ & Chocolate making & 2 & & 3 & & & & & & & & & 1 \\
\hline
\end{tabular}

In fact, offered framework of values indicates that categories and types of value are not completely disparate and, in many cases, types of value prioritised by entrepreneurs overlap or correspond to multiple groups.

\section{Conclusion, Limitations and Future Research}

In a time of increasing global connectedness, albeit with growing uncertainty, ambiguity and chaos; people turn towards known products and services, which have not only functional characteristics but can also satisfy their aesthetic and emotional needs. The increasing focus on creativity and innovation in business, including new approaches towards business operations and its aesthetic components in recent years, gave rise to the interest in craft and draw attention to entrepreneurial undertakings of the craft makers and value created in the sector. Thus, the main research question of this study was to reveal types of value created by craft entrepreneurs in the craft sector in Latvia. The authors answered this question by integrating various bodies of the literature with in-depth qualitative research using data obtained using grounded theory approach, incl. field study and semi-structured interviews. 
According to the results of the study, which involved different entrepreneurs, it was noticed that they all mentioned economic and developmental values as those that are integral components of the entrepreneurial process. However, they didn't place them first in their hierarchy of values but indicated that they are an integral part of what they do. Besides, most of the entrepreneurs mentioned cultural, aesthetic, artistic and traditional values, which leads to the finding that these values could distinguish the craft sector from the other sectors of the economy. As revealed during the study, craft entrepreneurs make a significant impact in value categories such as cultural, aesthetical, artistic, traditional and symbolic leading to the conclusion that the craft sector has great potential in terms of creative power, while helping to sustain national traditions and cultural heritage. The study indicated that craft entrepreneurs create different types and forms of value, from materialistic to idealistic by nature and from purely economic to social, cultural and transformational by the impact. Besides, the value created contributes differently across levels of impact (from personal to national and even international) facilitating tourism development and promoting the country and Latvian lifestyle overseas.

All research has limitations and in the present study, as in the majority of academic works, retrospective nature is the most common limitation. It makes the study vulnerable to bias as interviewees can comment on the outcomes of their actions in the past. Although cases selected for the study represented different types of businesses in the craft sector and there was an extensive diversity in the profile, the scale of business, and age of the entrepreneurs, those still represent only the chosen enterprises and only ones established in Latvia. Taking into consideration the great variety of studies in the field of entrepreneurship, the focus of this study was limited to value created by entrepreneurial ventures as perceived by entrepreneurs. For future research, it would be beneficial to explore other contexts (countries), to consider also other factors influencing value created - for instance, the influence of external context on entrepreneurial decisions or the specific instruments needed for better support of entrepreneurship in the craft sector in Latvia. Also, longitudinal as well as quantitative research would be beneficial to facilitate understanding of opportunity development in the local craft sector.

This study did not set an objective to insist on the validity of the findings - "prove" the results. This work is explorative to set the scene for future research in this direction. Nevertheless, this study provides a significant foundation for a more detailed analysis of entrepreneurship in the craft sector in Latvia to further probe its peculiarities.

\section{Bibliography}

1. Acs Z.J., Braunerhjelm P., Audretsch D.B. Carlsson B. (2009). The knowledge spillover theory of entrepreneurship. Small Business Economics, 32(1), 15-30. doi: 10.1007/s11187-008-9157-3

2. Baumol W.J. (1990). Entrepreneurship: productive, unproductive, and destructive. Journal of Political Economy, 98(5), 893-921. Retrieved from https://www.jstor.org/stable/2937617

3. Bettarini G. (2014). The Artistic Crafts Sector in Europe: Operative Plans and Strategic Visions. Florence: Innocrafts. Retrieved from https://issuu.com/ancitoscana/docs/3-eng

4. Birch D.L. (1979). The job generation process. Cambridge, MA: MIT Program on Neighbouring and regional Change.

5. Chapain C., Comunian R. (2010). Enabling and inhibiting the creative economy: The role of the local and regional dimensions in England. Regional Studies, 44(6), 717-734. doi: 10.1080/00343400903107728

6. Corbin J., Strauss A. (1998). Basics of Qualitative research. London: Sage. doi: 10.4135/9781452230153

7. Culture Label Agency. (2014). Cultural Innovation and Entrepreneurship in London. London: City of London Corporation. Retrieved from https://issuu.com/airbeem/docs/cultural-innovation-and-entrepreneu

8. Dormer P. (1997). Introduction. The salon de refuse? In P. Dormer (Ed.), The Culture of Craft. Manchester: Manchester University Press, 2-16.

9. Gangi J. (2015). The Synergies of Artistic and Entrepreneurial Action. The Journal of Arts management, Law, and Society, 45(4), 247-254. doi: 10.1080/10632921.2015.1088912

10. Gartner W.B. (1990). What are we talking about when we are talking about entrepreneurship? Journal of Business Venturing, 5(1), 15-28. doi: 10.1016/0883-9026(90)90023-M

11. Gartner W.B. (2001). Is there an elephant in entrepreneurship? Blind assumptions in theory development. Entrepreneurship: Theory and Practice, 25(4), 27-39.

12. Hébert R.F., Link A.N. (1982). The Entrepreneur: mainstream views and radical critiques. New York: Preager. 
13. Jakob D. (2013). Crafting your way out of the recession? New craft entrepreneurs and the global economic downturn. Cambridge Journal of Regions, Economy and Society, 6(1), 127-140. doi: 10.1093/cjres/rss022

13. Kirzner I.M. (1973). Competition and Entrepreneurship. Chicago, IL: University of Chicago Press.

14. Kirzner I.M. (1983). Entrepreneurs and the entrepreneurial function: a commentary. In J. Ronen (Ed.), Entrepreneurship. Lexington, MA: Lexington Books.

15. Klamer A. (2011). Cultural entrepreneurship. The Review of Austrian Economics, 24(2), 141-156. doi: $10.1007 / \mathrm{s} 11138-011-0144-6$

16. Kouhia A. (2012). Categorizing the meanings of craft: A multi-perspectival framework for eight interrelated meaning categories. Techne Serien - Forskning i Slöjdpedagogik och Slöjdvetenskap, 19(1), 25-40. Retrieved from https://journals.hioa.no/index.php/techneA/article/view/395

17. LEXICO. (2019). Dictionary. Retrieved from https://www.lexico.com/en/definition/craft

18. Lucie-Smith E. (1981). The Story of Craft. The Craftsman's Role in Society. Oxford: Phaidon. Retrieved from https://archive.org/details/storyofcraft00luci

19. McWilliams A., Siegel D. (2001). Corporate social responsibility: A theory of the firm perspective. Academy of management review, 26(1), 117-127. doi: 10.5465/amr.2001.4011987

20. Mečņika V., Hoerr M., Krieviņš I., Schwarz A. (2014). Smart textiles for healthcare: applications and technologies. In V. Dislere (Ed.), The Proceedings of the International Scientific Conference Rural Environment. Education. Personality (REEP), 7. Jelgava: LLU, 150-161. Retrieved from https://lufb.llu.lv/conference/REEP/2014/Latvia-Univ-Agricult-REEP-2014proceedings-150-161.pdf

21. Merriam-Webster. (2019). Craft. Retrieved from https://www.merriam-webster.com/dictionary/craft

22. Mowlah A., Niblett V., Blackburn J. Harris M. (2014). The value of arts and culture to people and society-An evidence review ( $2^{\text {nd }}$ ed.). Manchester: Arts Council England. Retrieved from https://www.artscouncil.org.uk/sites/default/files/download-

file/The_value_of_arts_and_culture_to_people_and_society_an_evidence_review.pdf

23. Patton M.Q. (2002). Qualitative research and evaluation methods ( ${ }^{\text {rd }}$ ed.). Thousand Oaks: CA: SAGE.

24. Pöllänen S. (2009). Contextualizing craft: Pedagogical models for craft education. International Journal of Art Design, 28(3), 249-260. doi: 10.1111/j.1476-8070.2009.01619.x

25. Pret T., Shaw E., Dodd S.D. (2016). Painting the Full Picture: The Conversion of Economic, Cultural, Social and Symbolic Capital. International Small Business Journal,34(8), 1004-1027. doi: $10.1177 / 0266242615595450$

26. Ratten V., Ferreira J.J. (2017). Future research direction for cultural entrepreneurship and regional innovation. International Journal of Entrepreneurship and Innovation, 21(3), 163-169. Retrieved from https://www.inderscience.com/info/dl.php?filename=2017/ijeim-5077.pdf

27. Rintamäki T., Kuusela H., Mitroen L. (2007). Identifying competitive customer value propositions in retailing. Managing Service Quality, 17(6), 621-634. doi: 10.1108/09604520710834975

28. Risatti H. (2007). A Theory of Craft: Functional and Aesthetic Expression. Chapel Hill: University of North Carolina Press.

29. Rosner D.K. (2009). Considering Craftsmanship. Berkeley: UC Berkeley School of Information.

30. Sirmon D.G., Hitt M.A., Ireland R.D. (2007). Managing firm resources in dynamic environments to create value: Looking inside the black box. Academy of Management review, 32(1), 273-292. doi: 10.5465/amr.2007.23466005

31. Throsby D. (2008). The concentric circles model of the cultural industries. Cultural Trends, 17(3), 147-164. doi: 10.1080/09548960802361951

32. Tregear A. (2005). Lifestyle growth or community involvement? The balance of goals of artisan food producers. Entrepreneurship and Regional Development, 17(1), 1-15. doi: 10.1080/08985620420002497777

33. Value Market Research. (2018). Global Arts and Crafts Market Report By Product (Drawing Pen, Paints And Stains, Craft Tools, And Others), Application (Home Use, Commercial Use, And Educational Use) And By Regions - Industry Trends, Size, Share, Growth, Estimation and Forecast, 2017-2026. Retrieved from https://www.valuemarketresearch.com/report/arts-and-crafts-market

34. Walley L.E.E., Taylor D.W. (2002). Opportunists, Champions, Mavericks...? A Typology of Green Entrepreneurs. Greener Management International, 38(1), 31-43. doi: 10.9774/GLEAF.3062.2002.su.00005

35. Yin R.K. (1994). Case study research - design and methods (2 ${ }^{\text {nd }}$ ed.). Thousand Oaks, CA: Sage Publications.

36. Zulaikha E., Brereton M. (2011). Innovation strategies for developing the traditional souvenir craft industry. In C: Cowled (Ed.) in Proceedings of International Postgraduate Conference on Engineering, Designing and Developing the Built Environment for Sustainable Wellbeing (eddBE2011), 1. Brisbane: Queensland University of Technology, 53-58. doi: 10.13140/2.1.3121.8886 